\title{
Natural Course of the Arteriovenous Malformations of the Brain Initially Presented by Hemorrhage: Analysis of a Clinical Series of 39 Patients
}

\section{Kanama ile Kendini Gösteren AVM'lerin Doğal Seyri:39 Olguluk Seri}

Goran TASIC, Vladimir JOVANOVIC, Branko DJUROVIC, Igor NIKOLIC, Milos JANICIJEVIC, Miroslav SAMARDZIC, Vaso ANTUNOVIC, Vojislav BOGOSAVLJEVIC

Clinical Centre of Serbia, Institute for Neurosurgery, Belgrade, Serbia, Yugoslavia

Correspondence address: Vojislav BOGOSAVLJEVIC / E-mail: neurobog@beotel.rs

\begin{abstract}
AIM: AVM because of outstanding tendency toward bleeding, even though 20 times more rare then aneurysm on the blood vessels of the brain and her own specific anatomical structure even today represents big neurosurgical challenge.

MATERIAL and METHODS: Series which is shown here consists of 39 patients which were hospitalized in the institute for neurosurgery of the Clinical Center of Serbia in the period between 1995 and 2004. This group was exposed to symptomatic therapy or it was estimated that surgery, embolization and radio surgery.

RESULTS: Combined type of venous drainage brings a high risk $(p<0.001)$ from repeated bleeding. Combined artery bringing from different flows $(p<0.05)$ contributes to genesis of 'steal phenomenon', in combination with deep venous drainage it presents predisposing anatomical characteristics for repeated bleeding $(p<0.001)$ according to our results should present AVM with dimensions 2.5 to $5 \mathrm{~cm}$ localized in eloquent zone of big brain with combined type of venous drainage and cobined artery bringing from vertebro-basilar flow and carotid flow.

CONCLUSION: Perception of natural course of AVM point to certainly more benign pathology in regard to other vascular malformations. Specific anatomical structure requires planning of treatment from case to case, most often combination of embolization, radio surgery and surgical treatment
\end{abstract}

KEYWORDS: AVM, Hemorrhage, Natural course

Öz

AMAÇ: AVM'ler anevrizmalara göre 20 kez daha nadir görülmelerine rağmen, kanama ile kendilerini gösterebildiklerinden önemli bir nöroşirürjikal sorundurlar.

YÖNTEM ve GEREÇ: Bu seride Sırbistan Klinik Merkezinde 1995 ile 2004 yılları arasında tedavi edilmiş olan 39 olgu sunulmaktadır. Bu olgulara semptomatik tedavi veya cerrahi, embolizasyon veya radyocerrahi uygulanmıştır.

BULGULAR: Çoklu venöz drenajın tekrarlayıcı kanama gelişmesinde yüksek risk oluşturduğu $(p<0.001)$ saptanmıştır. Çoklu arteriel besleyici bulunması ise çalma fenomenine yol açmaktadır $(p<0.05)$. Hassas bölge yerleşimli ve boyutları 2.5 ile $5 \mathrm{~cm}$ arasında olan AVM'lerde eğer çoklu besleyici ve derin drenaj veni var ise, kanama riski artmaktadır $(p<0.001)$.

SONUÇ: AVM'ler diğer damarsal sorunlara göre daha iyi huyludurlar. Her olgu kendi içinde değerlendirilmeli ve cerrahi, embolizasyon ve radyocerrahiden hangisinin uygun olacağına karar verilmelidir.

ANAHTAR SÖZCÜKLER: AVM, Doğal seyir, Kanama

\section{INTRODUCTION}

Arteriovenous malformations (AVM) of the brain as a separate entity were confirmed by the middle of the nineteenth century (14). AVMs represent a congenital disorder in the early differentiation of the arterial and venous blood vessels of the brain where occurs a direct contact between the arteries and veins whether in fistulous form or with inserted primordial capillary plexus $(6,28)$. This type of circulation 'steals' the blood from the surrounding brain ('steal' phenomenon) because the normal supply of the blood is distributed inside AVM bypassing to a great extent the surrounding normal brain $(6,8,10)$. AVM of the brain is dominantly initially presented by intracranial hemorrhage $(\mathrm{ICH})$ in 30 to $55 \%$ of cases in the period from the second to the fourth decade of life, by epileptic seizures, headache and progressive neurological deficit. $95 \%$ of AVMs become symptomatic before the age of $70(1,3,13,15)$. 
$\mathrm{ICH}$ is the principal cause of morbidity and mortality, and the size of AVM, type of the venous drainage and raised blood pressure in supplying arteries are distinguished as the pathoanatomical predisposing factors for generating the bleeding from AVM $(15,22,30)$.

Comparative studies show that annual risk for occurrence of the bleeding from AVM of the brain is $2-4 \%$ annually and it is followed by death outcome in $10 \%$ of cases and neurological deficit in $50 \%$ of cases $(7,19,21,27,31)$.

Since AVMs of the brain do not have such a high risk of repeated hemorrhage as aneurysms and an average incidence of $0.14 \%$, this makes possible elective approach when selecting the therapy option (surgery, embolization, radio surgery) $(9,18,20,31)$.

\section{MATERIAL and METHOD}

Our study includes a series of 39 patients with AVM of the brain who had not been submitted to any treatment method, except for the symptomatic therapy, and who were hospitalized and AVM diagnosed at the Institute for Neurosurgery Clinical Center of Serbia in the period from October 1995 until October 2004. Arteriovenous malformation diagnosis was definitely confirmed in all cases by way of cerebral panangiography (standard or digital substraction).

During the follow-up period the patients were not submitted to any alternative manner of causal treatment, such as surgery, embolization or radiotherapy. The patients from this series were not treated as it had been estimated that surgical procedure had a higher risk of postoperative invalidity than the natural course of the disease, or because the patient and his/her family refused treatment.

For the start follow-up time of the natural course of the disease was taken the moment when AVM was diagnosed in patients where the malformation clinically presented itself by hemorrhage.

The follow-up of the natural history of AVM was concluded at two terms: by definitely establishing the series and by starting the treatment of the same (for definitely untreated cases) and by the start term of the treatment (surgery, embolization, radiotherapy) for the patients who after the earlier foreseen follow-up period were submitted to one of the ways of causal treatment of AVM.

For representation and assessment of the clinical-anatomic AVM characteristics we used generally accepted system according to Spetzler Martin (SM index score) which means the assessment of the localization, AVM size and drainage type (superficial, deep, combined) as well as the final total value- grading (24). Neurological status and working and life capability were ranged according to values systematized in Karnofsky index (12). In order to test statistical significances and to check the hypotheses we used methods of descriptive and analytical statistics.

\section{RESULTS}

As regards the sex in the structure of the investigated patients male patients prevailed 23:16 (58.97\%: 41.03\%), and as regards the age, younger persons were predominant, 22 $(56.4 \%)$ were under the age of 30 . Mean age of all examined patients was $27.4 \pm 7.6$ years.

Variation interval for age ranged from 6-64 years. Until the conclusion of the series 37 or $94.9 \%$ of patients were followedup, and 2 or $5.1 \%$ of patients died.

The largest number of examined patients 21 or $53.8 \%$ were followed-up for longer than 36 months, i.e. over 3 years; 1336 months 14 or $35.9 \%$ patients; and less then 12 months 4 or $10.3 \%$ of patients were followed-up. The average follow-up time of all patients was $57.2 \pm 8.7$ months. The mean value of 32.0 months points to the length of the average three-year follow-up of all examined patients.

As shown in Table I, this group consists of 39 patients who had intracerebral hemorrhage (HIC) as initial sign in 22 cases or $56.4 \%$, intraventricular (HIV) had 3 or $7.7 \%$ patients and combined type (HIC, HIV, SAH) had 5 or $12.8 \%$ of examined patients; subarahnoidal hemorrhage $(\mathrm{SAH})$ as initial sign presented in 9 or $23.1 \%$ of examined patients.

Table I: Type and Total Number of Hemorrhages in Patients with Hemorrhages

\begin{tabular}{|c|r|r|}
\hline \multicolumn{1}{|c|}{ Characteristic } & Number \\
\hline 1.Type of hemorrhage & 22 & 56,4 \\
HIC & 9 & 23,1 \\
SAH & 3 & 7,7 \\
HIV & 5 & 12,8 \\
Combined & & 38,5 \\
\hline 2. Total number of hemorrhages & 15 & 46,2 \\
one & 18 & 7,7 \\
two & 3 & 5,1 \\
three & 2 & 2,6 \\
four & 1 & 100,0 \\
\hline five and more & 39 & \\
\hline
\end{tabular}


Without repeated, i.e. with one hemorrhage there were 15 or $38.5 \%$ of examined patients, and in repeated hemorrhages with 2 there were 18 or $46.2 \%$, with 3 there were 3 or $7.7 \%$, with 4 there were 2 or $5.1 \%$, and with 5 hemorrhages there was only 1 patient.

Having in mind the basic aims of our investigation, as well as our hypotheses, it was of essential interest to study the site and the significance of individual risk factors that cause the occurrence of repeated hemorrhages. In order to do that we analyzed two subgroups of patients: B1-1 with one hemorrhage, i.e. without repeated hemorrhages and B1-2 with two or more hemorrhages, i.e. with repeated hemorrhages. The largest number of investigated patients in both subgroups was followed-up for more than two years. The average follow-up length in subgroup B1-1 was 49.8 \pm 14.0 months, and in subgroup B1-2 it was 70.5 \pm 9.7 months, however that was not confirmed as statistically significant difference $(p>0.05)$, see Table II.

At the average length of the follow-up time which was 4.8 years, new hemorrhages occurred in 24 or $61.5 \%$ patients, with 58 episodes and with the hemorrhage/year rate $28.5 \%$. On the average in 3.5\% annually a new hemorrhage occurred in relation to the total number of the investigated patients, without statistically significant difference in relation to sex. Prevalence of the new hemorrhage episodes in investigated patients who were longitudinally followed-up up to 24 months was $37.5 \%$, from $25-48$ months it was $61.5 \%$, and in patients who were followed-up for 49 months and more it was $72.2 \%$. Statistical analysis did not confirm this rising trend as statistically significant $(X 2=2.821 ; p>0.05)$, see Table III.

In both investigated patient subgroups the persons of male sex were dominant, however the participation of these investigated patients was somewhat greater in the subgroup with repeated hemorrhages (62.5\%: 53.3\%), in the subgroup with repeated hemorrhages slightly prevailed participation of younger people (58.3\%: 53.3\%).

Statistical testing did not define significant differences between the investigated subgroups as regards the distribution of findings of the investigated characteristics ( $p>0.05)$, Table IV.

On admittance Karnofsky index of 80 and more was more frequent in patients with repeated hemorrhages $(25.0 \%$ : $6.7 \%)$, but without statistically significant difference ( $p>0.05$ ). However, mean value of Karnofsky index was statistically significantly higher in investigated patients who had repeated hemorrhages $(66.6 \pm 2.9 ; 56.0 \pm 3.7 ; p<0.035)$, Table V.

Table II: Length of Longitudinal Follow-up of Investigated Patients

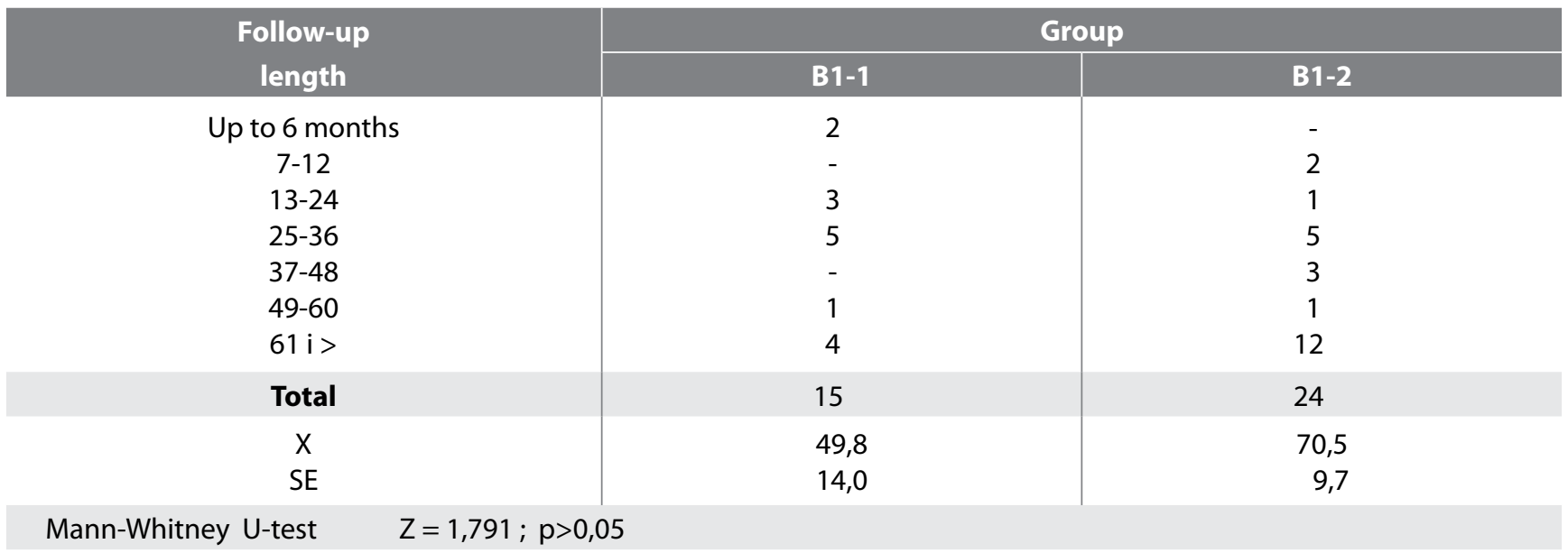

Table III: Prevalence of Repeated Hemorrhages in Reference to Longitudinal Follow-Up Length (31 Patients had Repeated Haemorrhage)

\begin{tabular}{|c|r|c|c|}
\hline Follow-up & & \multicolumn{2}{|c|}{ Repeated hemorrhages } \\
\cline { 2 - 4 } length & N & n & 37,5 \\
Up to 24 months & 8 & 8 & 61,5 \\
$25-48$ & 13 & 13 & 72,2 \\
49 and more & 18 & 24 & 61,5 \\
Total & 31 & 8 & \\
\hline
\end{tabular}

$X^{2}=2,821 ; D F=2 ; p>0,05$ 
The occurrence of new hemorrhages, as well as the rate of hemorrhage episodes/year was higher in investigated patients with index 80 and more (85.7\%: 56.2\%), i.e. (38.5: $25.5 \%)$, but without statistically significant difference ( $p>0.05$ ). In relation to the Karnofsky index level at the end of the follow-up period no significant differences were found in the investigated parameters ( $p>0.05)$, Table VI.
At shorter average follow-up time the rate hemorrhage/yrs was statistically significantly higher in arterial supply from VB confluence in relation to ACM (45.8\%: 10.6\%; $\mathrm{p}<0.01)$ also statistically significant was the supply from ACA confluence in relation to ACM confluence as a predisposing factor for hemorrhage (51.4\%: 10.6\%; $\mathrm{p}<0.01$ ). Multiple supply arterial network confirmed statistically significant place in

Table IV: Demographic and Anamnestic Characteristics in Patients with One (B1-1) and Two and More (B1-2) Repeated Hemorrhagies

\begin{tabular}{|c|c|c|c|c|c|}
\hline \multirow{3}{*}{ Characteristic } & \multicolumn{4}{|c|}{ Group } & \multirow{3}{*}{$\mathbf{P}$} \\
\hline & \multicolumn{2}{|c|}{ B1-1 } & \multicolumn{2}{|c|}{ B1-2 } & \\
\hline & $\mathbf{N}$ & $\%$ & $\mathbf{n}$ & $\%$ & \\
\hline $\begin{array}{l}\text { 1. Sex } \\
\qquad \begin{array}{l}M \\
F\end{array}\end{array}$ & $\begin{array}{l}8 \\
7\end{array}$ & $\begin{array}{l}53,3 \\
46,7\end{array}$ & $\begin{array}{r}15 \\
9\end{array}$ & $\begin{array}{l}62,5 \\
37,5\end{array}$ & $>0,05$ \\
\hline $\begin{array}{l}\text { 2. Age } \\
\begin{array}{l}\text { Up to } 30 \mathrm{yrs} . \\
31<\end{array}\end{array}$ & $\begin{array}{l}8 \\
7\end{array}$ & $\begin{array}{l}53,3 \\
46,7\end{array}$ & $\begin{array}{r}14 \\
10\end{array}$ & $\begin{array}{l}58,3 \\
41,7\end{array}$ & $>0,05$ \\
\hline $\begin{array}{l}\text { 3. Associated diseases } \\
\text { } \begin{array}{l}\text { Hypertension and diabetes } \\
\mathbf{\square} \text { others }\end{array}\end{array}$ & $\begin{array}{l}2 \\
2\end{array}$ & $\begin{array}{l}13,3 \\
13,3\end{array}$ & $\begin{array}{l}7 \\
3\end{array}$ & $\begin{array}{l}29,2 \\
12,5\end{array}$ & $>0,05$ \\
\hline Total & 15 & 100,0 & 24 & 100,0 & \\
\hline
\end{tabular}

B1-1: with one hemorrhage; B1-2: two and more hemorrhages

Table V: Karnofsky Index on Admittance in Patients with One (B1-1) and Two and More (B1-2) Repeated Hemorrhages

\begin{tabular}{|c|c|c|c|c|c|c|}
\hline \multirow{3}{*}{\multicolumn{2}{|c|}{ Characteristic }} & \multicolumn{4}{|c|}{ Group } & \multirow{3}{*}{$\mathbf{P}$} \\
\hline & & \multicolumn{2}{|c|}{ B1-1 } & \multicolumn{2}{|c|}{ B1-2 } & \\
\hline & & $\mathbf{N}$ & $\%$ & $\mathbf{n}$ & $\%$ & \\
\hline Karnofsky index & $\begin{array}{l}\leq 70 \\
80 \geq\end{array}$ & $\begin{array}{c}14 \\
1\end{array}$ & $\begin{array}{r}93,3 \\
6,7\end{array}$ & $\begin{array}{r}18 \\
6\end{array}$ & $\begin{array}{l}75,0 \\
25,0\end{array}$ & $>0,05$ \\
\hline & $\begin{array}{l}X \\
S E\end{array}$ & $\begin{array}{r}56,0 \\
3,7\end{array}$ & & $\begin{array}{r}66,6 \\
2,9\end{array}$ & & $<0,035$ \\
\hline
\end{tabular}

B1-1: with one hemorrhage; B1-2: two and more hemorrhages

Table VI: Bleeding Incidence in Reference to Karnofsky Index at the end of Longitudinal Follow-Up

\begin{tabular}{c|c|c|c|c|c} 
Characteristic & N & \multicolumn{2}{|c|}{$\begin{array}{c}\text { Occurrence of new } \\
\text { hemorrhages }\end{array}$} & Rate hemorrhage / yrs & $\begin{array}{c}\text { Mean follow-up time } \\
\text { (years) }\end{array}$ \\
Karnofsky index & & & & & \\
Annual
\end{tabular}


predisposition for bleeding from AVM. In examined patients with three types of arterial supply the rate hemorrhage/ yrs was significantly higher in relation to two types of supply present (52.0\%: 23.2\%; $p<0.05)$. In Table VII is shownt neuroradiological findings by conventional angiography.

The type of arterial supply was not statistically significantly different between the investigated groups of patients $(X 2=0.942 ; p>0.05)$, although the frequency of multiple supplies was higher in group B1-2 (62.5\%: 46.7\%). Also in group B1-2 AVMs localized in the left cerebral hemisphere are considerably more frequent $(50.0 \%)$, and in group B1-1 in the right hemisphere $(66.7 \%)$. However, in the manner of presentation of the distribution of findings they did not show statistically significant difference $(X 2=2.310 ; p>0.05)$.

The size of AVM and the value of Martin-Spetzler score did not show significant differences in the distribution of findings between patients without and with repeated hemorrhage episodes ( $p>0.05)$. However, as regards the drainage, differences in distribution of findings showed statistically significant difference $(X 2=7.764 ; \mathrm{p}<0.020)$. Namely, in patients where new hemorrhage episodes did not occur AVMs with deep drainage were dominant (80.0\%), and in patients with repeated hemorrhage episodes combined drainage predominated (58.3\%). In AVMs that presented with one hemorrhage episode, although the difference exists, combined drainage is more frequent and it is statistically considerably less significant (subgroup B1-1) Table VIII.

In accordance with the earlier mentioned findings, we have found that hemorrhages occur significantly more frequent in combined drainages (87.5\%: $42.8 \% ; \mathrm{p}<0.01$ ), as well as the hemorrhage episode/yrs rate (33.6\%: 22.6\%; $\mathrm{p}<0.05$ ), in relation to findings in deep drainages. The size of AVM, as well as the finding of Martin-Spetzler score did not show significant differences in frequency of the occurrence of new hemorrhages in investigated patients, as well as the hemorrhage episode/yrs rate. However, we need to stress that the average number of hemorrhage episodes per year is considerably greater when the size of AVM is from $2.6-5.0 \mathrm{~cm}$ (3.7) and 5.1 and more $\mathrm{cm}$ (3.8), also in deep drainages (4.4) in relation to superficial (2.5) and combined ones (3.0), Table IX.

Analyzing the variance of the investigated characteristics statistically significant difference between the patient subgroups without and with present repeated hemorrhage episodes showed Karnofsky index on admittance $(p=0.0307)$ and the drainage type $(p=0.0115)$.

Analyzing discriminatively we arrived at a statistically significant function with the following parameters (canonical $r=0.5191 ; r 2=0.2694$; Wilks Lambda 0.7305; $X 2=11.304$; $p<0.0035)$.

From the obtained function, convincingly greatest discriminative value shows drainage variable, where the correlation with the discriminative factor amounts to 0.71997 , then Karnofsky index upon admittance with correlation of 0.60833 and Martin-Speltzer index with correlation of 0.49438 . Less discrimination, but still with a significant influence, showed AVM size and the length of longitudinal follow-up. All the other characteristics have no influence on dividing these two sets of investigated patients.

Investigated variables were included into the model of multivariant logistic regression, also with the aim to define

Table VII-A: Bleeding Incidence in Reference to the Type of Arterial Supply and Localization of Change

\begin{tabular}{|c|c|c|c|c|c|c|}
\hline Characteristic & $\mathbf{N}$ & $\begin{array}{r}\text { Occurre } \\
\text { hemo } \\
n\end{array}$ & $\begin{array}{l}\text { of new } \\
\text { gies } \\
\%\end{array}$ & Rate hemorrhage / yrs & $\begin{array}{c}\text { Mean follow-up time } \\
\text { (years) }\end{array}$ & $\begin{array}{c}\text { Xep } \\
\text { Annual }\end{array}$ \\
\hline $\begin{array}{l}\text { 1. Type of arteria } \\
\text { supply } \\
\text { VB } \\
A C M \\
A C A \\
A C l\end{array}$ & $\begin{array}{l}7 \\
5 \\
4 \\
1\end{array}$ & $\begin{array}{l}4(13) \\
2(4) \\
3(6) \\
-\end{array}$ & $\begin{array}{c}57,1 \\
40,0 \\
75,0 \\
-\end{array}$ & $\begin{array}{c}45,8 \%{ }^{*} \\
10,6 \% * \\
51,4 \% * \\
-\end{array}$ & $\begin{array}{l}4,06 \\
7,55 \\
2,92 \\
2,17\end{array}$ & $\begin{array}{c}2,2 \\
9,4 \\
1,9 \\
-\end{array}$ \\
\hline Total & $\begin{array}{l}1 \\
7\end{array}$ & $9(23)$ & 52,9 & $28,7 \%$ & 4,71 & 3,5 \\
\hline $\begin{array}{l}\text { Two } \\
\text { Three }\end{array}$ & $\begin{array}{l}1 \\
6 \\
6\end{array}$ & $\begin{array}{r}10(23) \\
5(12)\end{array}$ & $\begin{array}{l}62,5 \\
83,3\end{array}$ & $\begin{array}{l}23,2 \% * * \\
52,0 \% * *\end{array}$ & $\begin{array}{l}6,19 \\
4,04\end{array}$ & $\begin{array}{l}4,3 \\
2,0\end{array}$ \\
\hline Total & $\begin{array}{l}2 \\
2\end{array}$ & $15(35)$ & 68,2 & $28,4 \%$ & 3,49 & 3,5 \\
\hline
\end{tabular}


those variables that contribute to frequency - the occurrence of the new hemorrhage episodes. Analysis results have shown that the drainage has the greatest contribution, then comes
Karnofsky index on admittance, slightly less the condition graded by Martin-Spetzler score and AVM size.

Table VII-B: Neuroradiological Findings (Angiography \& CT) of AVM

\begin{tabular}{|c|c|c|c|c|c|}
\hline $\begin{array}{l}\text { Patient } \\
\text { (Initials and age) }\end{array}$ & Sex & $\begin{array}{l}\text { Diametar } \\
(\mathrm{cm})\end{array}$ & Localisation & Arterial supply & Drainage \\
\hline AV 26 & M & 6 & Left cerebellar hemisphere & VB & deep \\
\hline GB 45 & $\mathrm{~F}$ & 2.7 & Right parietal paraventricular & $M C A, A P$ & combined \\
\hline DjB 64 & M & 2.5 & Right basal ganglia & ACA bill. & deep \\
\hline IS 38 & $\mathrm{~F}$ & 4.2 & Right parietal lobe & ACA, MCA & combined \\
\hline LA 29 & $\mathrm{~F}$ & 4.2 & Left insula & MCA & superficial \\
\hline MM 55 & M & 3.7 & Pons & PCA, PICA & deep \\
\hline $\mathrm{Mm} 40$ & M & 4.3 & Left basal ganglia & MCA, ACA, AChoA & deep \\
\hline MG 35 & M & 4.5 & Left basal ganglia and III ventricle & AChoA, AChoP & deep \\
\hline PM 17 & $\mathrm{~F}$ & 3.2 & Corpus callosum & $A C A, M C A$ & deep \\
\hline RK 50 & $\mathrm{~F}$ & 1.1 & Brainstem & VB & deep \\
\hline SV 50 & M & 2.7 & Right occipital lobe & PCA, A.calosomarginalis & superficial \\
\hline TA 18 & M & 5.8 & Right basal ganglia & $M C A, A P, A C E$ & combined \\
\hline AV 25 & M & 2.5 & Brainstem & ACP bill et AchoP & deep \\
\hline BB 26 & $\mathrm{~F}$ & 3.5 & Left parietal lobe & AChoP, MCA ACoA & deep \\
\hline Blj 32 & $\mathrm{~F}$ & 6.2 & Corpus callosum & MCA bill, AP, PCA & deep \\
\hline IG 23 & M & 6.3 & Left frontal lobe & ACA bill, PCA & combined \\
\hline LS 25 & $\mathrm{~F}$ & 4.1 & Corpus callosum & $\mathrm{AP}, \mathrm{ACHoP}$ & deep \\
\hline MM 22 & $\mathrm{~F}$ & 5.7 & Right temporal lobe & AchoA, SCA, ACA & deep \\
\hline MG 55 & $M$ & 2.8 & Right basal ganglia & $\mathrm{MCA}, \mathrm{ACA}$ & deep \\
\hline MJ 20 & $\mathrm{~F}$ & 3 & Right cerebellar hemisphere & PICA bill & deep \\
\hline MD 35 & M & 2.7 & Right temporoparietal & ACA & combined \\
\hline SS 22 & M & 2.5 & Basal ganglia and III ventricle & AChoA, AP & deep \\
\hline SV 36 & M & 3 & Right motor cortex & $M C A, A C A$ & deep \\
\hline SN 57 & $\mathrm{~F}$ & 2.6 & Right parietooccipital & $\mathrm{MCA}, \mathrm{ACA}$ & deep \\
\hline HI 33 & $\mathrm{~F}$ & 5.9 & Right motor cortex & MCA, ACA, AChoP & combined \\
\hline MD 63 & M & 4.7 & Right parietooccipital & ACA, PCA & combined \\
\hline SV 35 & M & 3.7 & Left motor cortex & MCA, ICA, AChoP & combined \\
\hline$J V 55$ & $\mathrm{~F}$ & 5.8 & Left motor cortex & ACA bill & combined \\
\hline BB 13 & M & 4.2 & Right frontal lobe & MCA & combined \\
\hline EN 45 & M & 3.7 & Right motor cortex & $A P, M C A$ & deep \\
\hline DjD 44 & M & 6.3 & $\begin{array}{l}\text { Right motor cortex and basal } \\
\text { ganglia }\end{array}$ & $M C A, P C A, A P$ & combined \\
\hline HR 21 & $\mathrm{~F}$ & 6.9 & Cerebellum & VB & deep \\
\hline KG 25 & M & 2.3 & Right parietal lobe & MCA & combined \\
\hline MD 36 & M & 4.3 & Left motor cortex & MCA,ACA bill, AChoP & combined \\
\hline KB 24 & M & 5.7 & Left thalamus and mesencephalon & $M C A, A P, P C A$ & combined \\
\hline SZ 22 & $\mathrm{~F}$ & 4.2 & Pineal region & AP bill, PCA & deep \\
\hline PJ 34 & M & 2.3 & Right cerebellar hemisphere & PICA, AICA & deep \\
\hline LS 22 & $\mathrm{~F}$ & 6.2 & Left motor cortex & ACA, MCA, PCA & combined \\
\hline ZD 46 & $M$ & 5.7 & Corpus callosum & ACA, MCA, PCA & deep \\
\hline
\end{tabular}


Table VIII: Anatomical Characteristics of AVM in Patients with One (B1-1) and Two and More (B1-2) Repeated Hemorrhages

\begin{tabular}{|c|c|c|c|c|c|}
\hline \multirow{3}{*}{ Characteristic } & \multicolumn{4}{|c|}{ Group } & \multirow{3}{*}{$\mathbf{P}$} \\
\hline & \multicolumn{2}{|c|}{ B1-1 } & \multicolumn{2}{|c|}{ B1-2 } & \\
\hline & $\mathbf{N}$ & $\%$ & $\mathbf{n}$ & $\%$ & \\
\hline $\begin{array}{l}\text { 1. Size of AVM } \\
\qquad \begin{array}{l}\text { Up to } 2,5 \mathrm{~cm} \\
2,6-5,0 \\
5,1 \text { and more }\end{array}\end{array}$ & $\begin{array}{l}4 \\
8 \\
3\end{array}$ & $\begin{array}{l}26,7 \\
53,3 \\
20,0\end{array}$ & $\begin{array}{l}9 \\
7 \\
8\end{array}$ & $\begin{array}{l}37,5 \\
29,2 \\
33,3\end{array}$ & $>0,05$ \\
\hline $\begin{array}{l}\text { 2. Drainage } \\
\qquad \begin{array}{l}\text { Superficial } \\
\text { Deep } \\
\text { Combined }\end{array}\end{array}$ & $\begin{array}{r}1 \\
12 \\
2\end{array}$ & $\begin{array}{r}6,7 \\
80,0 \\
13,3\end{array}$ & $\begin{array}{r}1 \\
9 \\
14\end{array}$ & $\begin{array}{r}4,2 \\
37,5 \\
58,3\end{array}$ & $\begin{array}{l}X^{2}=7,764 ; D F=2 \\
p<0,020 \\
L R=8,450 ; p<0,015 \\
C=0,407 ; p<0,02\end{array}$ \\
\hline $\begin{array}{l}\text { 3. M-S score } \\
\qquad \begin{array}{l}1 \\
2-3 \\
4-5\end{array}\end{array}$ & $\begin{array}{r}- \\
5 \\
10\end{array}$ & $\begin{array}{c}- \\
33,3 \\
66,7\end{array}$ & $\begin{array}{r}- \\
9 \\
15\end{array}$ & $\begin{array}{c}- \\
37,5 \\
62,5\end{array}$ & $>0,05$ \\
\hline Total & 15 & 100,0 & 24 & 100,0 & \\
\hline
\end{tabular}

B1-1: with one hemorrhage; B1-2: two and more hemorrhages

Table IX: Bleeding incidence in reference to the size of AVM, drainage type and Martin-Spetzler score

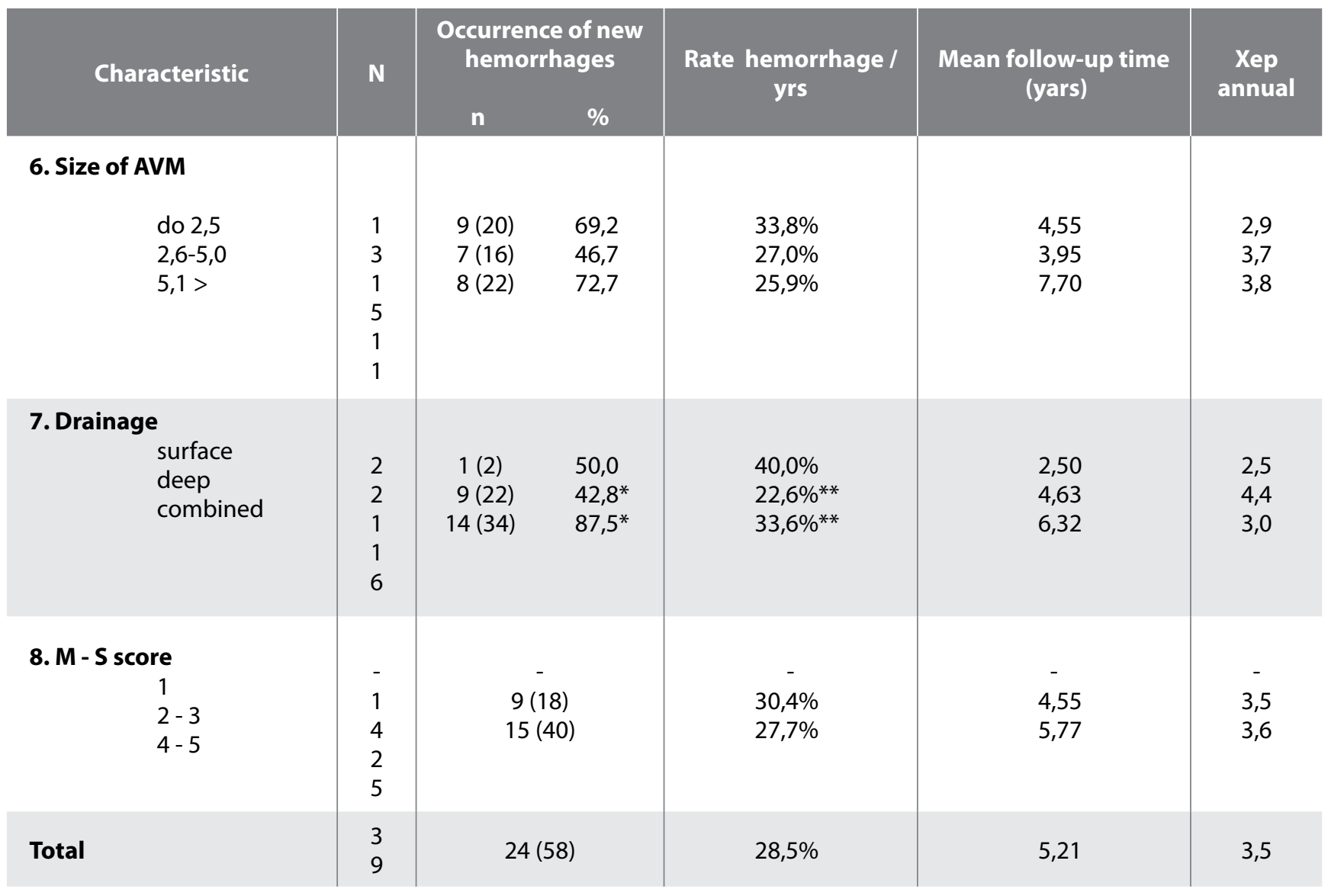




\section{DISCUSSION}

Initial presentation by bleeding was recorded in 39 patients. The average age of all investigated patients was $27.4 \pm 7.6$ years. Prevalence of the new hemorrhage episodes in patients longitudinally followed-up up to 24 months was $37.5 \%$, from 25-48 months $61.5 \%$ and in patients followed-up for 49 months and more $72.2 \%(\mathrm{X} 2=2.821 ; \mathrm{p}>0.05)$, and the presence of associated systemic diseases had no influence on the increase of the tendency to bleeding. American and Swedish authors point to homogeneity of the results of the natural course of AVM of the brain regardless of the nationality $(2,5)$. Parkinson points out that initial presentation of AVM of the brain by hemorrhage occurs between 20 and 40 years of age, with a slight predominance of males, without increasing the incidence of bleeding due to associated systemic diseases, and that the risk from bleeding is constant in the course of the follow-up period, regardless of age (19). During the cumulative follow-up period of 953 months for the patients. With this manner of presentation, 24 episodes of repeated bleeding were recorded, and that represents a cumulative risk of $3.33 \%$ per year. Namely, patients who once experience bleeding from an arteriovenous malformation are under constant risk of $3.33 \%$ annually to experience a repeated bleeding. The arrived at value is in accordance with results of Forster - 3\% and Martin and Spetzler 2-3\% $(5,23)$. Nusbaum cites that the risk from hemorrhage is identical both in AVM that presented with bleeding and in those that had no hemorrhage, and that risk amounts to $3-4 \%$ annually (17).

After initial hemorrhage our patient population had significant neurological deficit that in $82 \%$ of cases was presented by the value of Karnofsky index less than 70, meaning that these patients could take care of themselves with effort or with significant assistance from another person but that deficit did not get worse until the end of the follow-up interval, regardless of the number of repeated hemorrhages. However, significant recovery was recorded in the group of patients who experienced more episodes of repeated bleeding. Statistical confirmation $(p<0.035)$ that mean value of Karnofsky index is considerably higher in the group with repeated hemorrhages is in accordance with the results of Brown who presented a series of patients with AVM of the brain treated at the Mayo Clinic and stressed that an average of 12 months was needed for the recovery of the pyramidal deficit and cognitive functions, and that seemingly easy recovery may dissuade the patient from the proposed surgery (20).

According to our results the predisposing factors for hemorrhage from AVM are: arterial supply from the vertebrobasilar confluence with absolute statistical confirmation $(p<0.01)$, multiple arterial supplies from different arterial confluences $(p<0.05)$ with a remark that statistically significantly higher hemorrhage rate is from the confluence of the anterior cerebral artery than from the confluence of the middle cerebral artery $(p<0.01)$. The significance of supply arteries is specially stressed in literature, as the supply arteries are easily identified by arteriography (1). These arteries are abnormal both anatomically and physiologically and they may be in connection with AVM in three forms: as terminal arteries - ending in AVM, transit arteries - passing through AVM and giving branches that participate in its irrigation and transient arteries - that only pass through the malformation not participating in its architecture $(25,26)$. Analyzing AVM, Yasargil mentions the existence of 60 possible combinations of arterial supply blood vessels for each lesion (31). The greatest decrease of the systemic pressure happens where the supply arteries pass into $A V M$, and as the certain indicator of the presence of 'steal' phenomenon is distinguished the length of arterial supply longer than $8 \mathrm{~cm}$ measured from the level of Wilis hexagon $(16)$. Obtained statistical values $(p<00.1)$ that point to the location domination of the left hemisphere as the factor, which favors the occurrence of bleeding, has not been confirmed by literature and we think it occurred as a result.

Drainage veins have 6-10 times greater distensibility than supply arteries and they can contain blood volume three times greater than the arteries, and their compliance is 18-30 times greater then in arteries (4). Obtained results confirmed the significance of the vein type of drainage from AVM as predisposing factor for the occurrence of bleeding. In patients with one bleeding during the follow-up statistically significant domineers the form of deep venous drainage, while in patients with repeated bleeding domineers the combined venous drainage $(X 2=7.764, p<0.02)$ with significant predomination of the combined drainage $(p<0.5)$. Distribution of values of the Spetzler Martin index did not show statistically significant difference between the patients without and those with repeated hemorrhages, but the average number of annual hemorrhage episodes is considerably greater if the size of AVM is over $2.5 \mathrm{~cm}$ in diameter $(p<0.01)$. Kader in the series of 449 patients find hemorrhage as initial symptom in AVMs smaller than $2.5 \mathrm{~cm}$ in $90 \%$ of cases, in lesions of $2.5-5 \mathrm{~cm}$ in $52 \%$ of cases, while in lesions larger than $5 \mathrm{~cm}$ in $50 \%$ of cases (11).

Spetzler-Martin grading system represents statistical confirmation that neurosurgeons and neuroradiologists have coordinated attitudes as regards the anatomical characteristics of AVM of the brain that would be predictors of the bad outcome for the patient if left to the natural course of the disease. However, this grading system has recently been submitted to criticism. Analyzing the series of 224 patients with AVM of the brain Rose points out that errors are present from subjective as well as objective reasons. Namely, as regards the size of the malformation neurosurgeons are more inclined to preoperatively assess diameter of malformation and the total value of SM score bigger than the neuroradiologists. The disagreement is also manifested in the assessment of the type of the drainage, especially in cases of malformation that has a small, deep drainage vein and a dominant, wide superficial vein (1). It is also difficult to estimate the localization of AVM in border cases, i.e. in zones that are in the immediate vicinity of the so called eloquent zones - somatosensor and motor cortex, speech center, visual cortex, hypothalamus, thalamus, capsula interna, brain stem, cerebelar pedunculi and deep central nuclei (29). 


\section{CONCLUSIONS}

The results of our investigations that refer to the natural course of the disease in 39 patients with AVM enable us to draw the following conclusions. Demographic characteristics of the patients, as well as the presence of associated diseases have not shown statistically significant influence on the occurrence of new episodes of the disease ( $p>0.05)$.

The condition of patients at the start of the disease estimated through average Karnofsky index showed significant interdependence with the occurrence of the new episodes of the disease $(p<0.035)$. Namely, the patients in excellent condition with or without minor neurological deficit seemingly healthy after the first attack showed considerably more frequent tendency to have repeated episodes of the disease as regards the patients who during the initial phase of the presentation of the disease suffered considerable neurological deficit.

The combined type of the venous drainage within anatomical characteristics of AVM has significant influence on the occurrence of new episodes of the disease $(p<0.01)$ and on the incidence of the hemorrhage/yrs rate, which means that the type of malformation where the combined type of drainage is represented may be considered as the predominant, predisposing factor for the presentation of AVM by bleeding.

The type of arterial supply $(p<0.01)$ and the presence of several arterial supplies from different confluences $(p<0.05)$ represent statistically significant factors in the prevalence of bleeding from AVM. As the dominant, predisposing factor for the bleeding from AVM turned out to be the supply from vertebrobasilar confluence.

In a specific situation of relatively small series of investigated patients as ours (39), the value of Martin-Spetzler index did not turn out to be statistically significant predisposing factor for the manner of initial presentation of AVM, as well as for the weight of expected morbidity and mortality, however it should be stressed that the average number of annual hemorrhage episodes is considerably greater when the size of AVM is $2.5 \mathrm{~cm}$ and more.

Generally we may conclude that AVM of the brain as regards the entire range of neurological diseases pertain to benign lesions, and that demands patient and strategically wellprepared therapy approach.

Analyzing our series of 39 patients during the average followup of 5 years and 4 months we may propose the following model of the natural course of AVM:

After the initially presented bleeding there remains 3.33\% annual risk of repeated bleeding, with remark that repeated hemorrhages are statistically significantly more frequent in patients with higher Karnofsky index value. The total mortality during this follow-up period is $5.3 \%$ with cumulative survival probability of 0.9217 after 30 months.
Hemorrhages are considerably more frequent from a medium sized AVM $(2.5-5 \mathrm{~cm})$, localized in the eloquent zone of the brain, with combined type of the venous drainage, arterial supplies from the vertebrobasilar confluence, confluence of the anterior cerebral artery or even combined arterial supply.

\section{REFERENCES}

1. Al-Shahi R, Pal N, Lewis SC, Bhattacharya JJ, Sller RJ, Warlow $\mathrm{CP}$ : Observer agreement in the angiographic assessment of arteriovenous malformations of the brain. Stroke 33: 1501-1508, 2002

2. Brown RD, Wiebers DO, Torner JC, O Falon WM: Frequency of intracranial hemorrhage as a presenting symptom and subtype analysis:a population-based study of intracranial vascular malformations in Olmsted County, Minnesota. J Neurosurg 85:29-32, 1996

3. Fleetwood IG, Marcellus M, Levy RP, Marks MP, Steinberg GK: Deep arteriovenous malformationsof the bassal ganglia and thalamus: Natural history. J Neurosurg 98:747-750, 2003

4. Folkow B, Sivertsson R: Adaptive changes in "reactivity"and wallumen ratio in cat blood vessels exposed to prolonged transmural pressure diference. Life Sci 7(Part I):1283-1289, 1968

5. Forster DMC, Steiner L, Hakanson S: Arteriovenous malformations of the brain.A long-term clinical study. J Neurosurg 37:562-570, 1972

6. Gault J, Sarin H, Awadallah NA, Shenkar R, Awad IA: Pathobiology of Human Cerebrovascular Malformations: Basic Mechanisms and Clinical Relevance. Neurosurgery 55: 1-17, 2004

7. Graf CJ, Perret GE, Torner JC: Bleeding from cerebral arteriovenous malformations as a part of their natural history. J Neurosurg 58:331-337, 1983

8. Hai J, Ding M, Guo Z, Wang B: A new rat model of chronic cerebral hypoperfusion associated with arteriovenous malformations. J Neurosurg 97:1198-1202, 2002

9. Heros RC, Karosue K, Diebold PM: Surgical excision of cerebral arteriovenous malformations: Late results. Neurosurgery 26:570, 1990

10. Iwama T, Hayashida K, Takahashi JC, Nagata I, Hashimoto $\mathrm{N}$ : Cerebral hemodynamics and metabolism in patients with cerebral arteriovenous malformations: An evaluation using positron emission tomography scanning. J Neurosurg 97:1314-1321, 2002

11. Kader A, Young WL, Spellman JP, Henning M, Sciacca R, Mohr JP, Stein B: The Influence of Hemodynamic and Anatomic Factors on Hemorrhage from Cerebral Arteriovenous Malformations. Neurosurgery 34:801-808, 1994

12. Karnofsky D, Burchenal JH, Armistead GC Jr: Triethylene in the treatment of neoplastic disease. Arch Int Med 87:477-515, 1951

13. Luessenhop AJ, Rosa L: Cerebral arteriovenous malformations. Indications for and results of surgery, and the role of intravascular techniques. J Neurosurg 60:14-22, 1984 
14. Luschka H: Cavernose Blutgeschwulst des Gehirns. Virchows Arch 6:458-470, 1854

15. Marco S, Porter P, ter Brugge $K$, Montanera W, Wilinsky R, Wallace $C$ : Large and deep brain arteriovenous malformations are associated with risk of future hemorrhage. Stroke 33: 1220-1224, 2002

16. Nornes H: Quantitation of altered hemodynamics. In: Wilson CB, Stein BM, eds. Intracranial Arteriovenous Malformations. Baltimore: Williams\&Wilkins, 1984:32-43

17. Nusbaum ES, Heros RC, Camarata PJ: Surgical Treatment of Intracranial Arteriovenous Malformations with an Analysis of Cost-Effectiveness. Clin Neurosurg 348-369, 1995

18. Ogilvy CS, Stieg PE, Awad I, Brown RD Jr, Kondziolka D, Rosenwasser R, Young WL, Hademenos G: Special Writing Group of the Stroke Council, American Stroke Association: AHA Scientific Statement: Recommendations for the management of intracranial arteriovenous malformations: $A$ statement for healthcare professionals from a special writing group of the Stroke Council, American Stroke Association. Stroke 32:1458-1471, 2001

19. Parkinson D, Bachers G: Arteriovenous malformations. Summary of 100 consecutive supra-tentorial cases. J Neurosurg 53:285-299, 1980

20. Rigamonti D, Spetzler RF, Johnson PC, Drayer BP, Carter LP, Uede T: Cerebral vascular malformations. BNI Quarterly 3: 18-28, 1987

21. Selman WR TR, Ratcheson RA: Intracranial arteriovenous malformations: Patient evaluation and consideration for treatment. In: Batjer HH CL, Friberg L eds. Cerebrovascular Disease. Philadelphia: Lippincott-Raven, 1997:679-690

22. Spetzler R, Hargraves R, Mc Cormick P, Zabramski JM, Flom RA, Zimmerman RS: Relationship of perfusion pressure and size to risk of hemorrhage from arteriovenous malformations. J Neurosurg 76:918-923, 1992
23. Spetzler RF, Martin MA: A proposed grading system for arteriovenous malformations. J Neurosurg 65:476-483, 1985

24. Spetzler RF, Martin NA, Carter LP, Flom RA, Raudzens PA, Wilkinson E: Surgical management of large AVM s by staged embolization and operative excision. J Neurosurg 67:17-28, 1987

25. Spetzler RF, Modic M, Bonstelle C: Spontaneous opening of large occipital-vertebral artery anastomosys during embolization. Case report. J Neurosurg 53:849-850, 1980

26. Spetzler RF, Wilson CB, Weinstein P, Mehdorn M, Townsend $J$, Telles D: Normal perfusion pressure breakthrough theory. Clin Neurosurg 25:651-672, 1978

27. Tortosa EG, Sychra JJ, Martin EM, Artega M, Gaviria M, Pavel DG, Dujovny M, Ausman J: Postoperative Cognitive and Single Photon Emission Computed Tomography Assesment of Patients with Resection of Perioperative High-risk Arteriovenous Malformations. Neruosurgery 36:447-457, 1995

28. Uranishi R R, Baev NI, Ng PY, Kim JH, Awad IA: Vascular smooth muscle cell differentiation in human cerebral vascular malformations. Neurosurgery 48:359-368, 2001

29. Vates EG IM, Wilson CB, Mc Dermott MW, Halbach VV, Roberts TPL, Rowley HA: Magnetic Source Imaging Demonstrates Altered Cortical Distribution of Function in Patients with Arteriovenous Malformations. Neurosurgery 51:614-627, 2002

30. Vinuela F, Nombela L, Roach MR, Fox AJ, Pelz DM: Stenotic and occlusive disease of the venous drainage system of deep brain AVMs. J Neurosurg 63:180-184, 1985

31. Yasargil MG: Microneurosurgery Vol IIIB Stutgart: Georg Thieme Verlag, 1988 